\title{
38. OCEAN DRILLING PROGRAM LEG 103 BIOSTRATIGRAPHIC SYNTHESIS ${ }^{1}$
}

\author{
M. Moullade, ${ }^{2}$ J. L. Applegate,${ }^{3}$ J. A. Bergen, ${ }^{3}$ J. Thurow, ${ }^{4}$ P. S. Doyle, ${ }^{5}$ W. S. Drugg, ${ }^{6}$ \\ D. Habib, ${ }^{7}$ E. Masure, ${ }^{8}$ J. Ogg, ${ }^{9}$ and J. Taugourdeau-Lant ${ }^{10}$
}

\section{INTRODUCTION}

The stratigraphy of the Mesozoic-Cenozoic sedimentary sequence recovered from the western Galicia margin during Ocean Drilling Program (ODP) Leg 103 was derived from the study of a number of discrete sections. Technical problems prevented drilling of the deep, single reentry hole that was originally planned. Nevertheless, sufficient biostratigraphic data were obtained from eight holes (637A, 638B, 638C, 639A, 639D, 640A, 641A, and $641 \mathrm{C}$ ) to date the sequence collectively as late Tithonian to Quaternary and to attempt correlation of the various sections. The chronostratigraphic interpretations presented for each stage are based on the distribution of planktonic and benthic foraminifers, calcareous nannofossils, radiolarians, dinoflagellate cysts, spores and pollen grains, calpionellids, and ichthyoliths. Magnetostratigraphic data are included for correlation purposes. Figures 1-7 schematically illustrate the biostratigraphic and magnetostratigraphic data, in comparison to the stratigraphy of the lithologic units.

\section{MESOZOIC}

\section{Hole 639D (Fig. 1)}

Carbonate rocks of Late Jurassic age occur within the interval from Cores 103-639D-13R to 103-639D-3R. The calpionellids Crassicollaria massutiniana and Crassicollaria brevis have rare occurrences in Core 103-639D-5R. Their presence indicates the Crassicollaria A Zone (middle late Tithonian). Calcareous nannofossils of late Tithonian age (e.g., Polycostella beckmannii), occur in the interval from Cores 103-639D-10R to 103639D-6R. The shallow-water benthic foraminiferal assemblages, including Anchispirocyclina lusitanica in particular, point to a Tithonian age for the entire carbonate sequence, including the dolomitic section of Cores 104-639D-4R and 104-639D-3R that overlies the limestone section.

Paleomagnetic measurements were made on Cores 103-639D$13 R$ to $103-639 D-5 R$. The predominance of normal polarity in these cores is consistent with the late Tithonian age indicated by the microfossils. The polarity pattern indicates Chrons M19/ M20 and possibly M21.

${ }^{1}$ Boillot, G., Winterer, E. L., et al., 1988. Proc. ODP, Sci. Results, 103: College Station, TX (Ocean Drilling Program).

2 Laboratoire de Micropaléontologie et Géologie Marines, Université de Nice, Nice, France.

${ }^{3}$ Department of Geology, Florida State University, Tallahassee, FL.

${ }^{4}$ Institut und Museum für Geologie und Paläontologie, Universităt Tübingen, Tübingen, Federal Republic of Germany.

5 Scripps Institution of Oceanography, University of California, San Diego, La Jolla, CA.

6 Chevron Oil Field Research Company, LaHabra, CA.

${ }^{7}$ Queens College, Flushing, NY.

8 Laboratoire de Micropaléontologie, Département de Géologie Sédimentaire, Université Pierre et Marie Curie, Paris, France.

${ }^{9}$ Department of Earth and Atmospheric Science, Purdue University, West Lafayette, IN.

${ }^{10}$ Laboratoire de Micropaléontologie, Université Paris VI, Paris, France.

\section{Hole 639A (Fig. 2)}

Dolomite recovered in Cores 103-639A-10R and 103-639A$9 \mathrm{R}$ and the core catcher of Core 103-639A-8R disconformably underlies a 50-m-thick section of yellow marl and marlstone. The dolomite section of Hole 639A contains no age-diagnostic fossils; thus, its age equivalence to the Hole 639D dolomite can not be proven. The abundant calpionellids (Calpionellites $\mathrm{E}$ Zone) in the overlying marl/marlstone section indicate an early Valanginian (precisely middle early Valanginian) age. Calcareous nannofossils (CC3a, Tubodiscus verenae Subzone) and smaller benthic foraminifers (C3, Lenticulina busnardoi Subzone) also suggest an early (not earliest) Valanginian age. Thus, the reversed polarity zone found in the interval from the lower part of Core 103-639A-6R to Core 103-639A-8R is Chron M13 based on the fossil evidence.

\section{Holes 638B and 638C (Fig. 3)}

Together, drilling at Holes 638B and $638 \mathrm{C}$ recovered more than $350 \mathrm{~m}$ of sediments of Early Cretaceous age. Age assignments are provided by five groups of microfossils; significant disturbances resulting from terrigenous turbidite sedimentation render interpretation of the magnetostratigraphic record of this sequence tentative. We propose the following interpretations.

\section{Age Relationship between the Hole 639A Valanginian Marls and the Hole 638C Sandstones}

Calcareous nannofossils indicate that most of the sequence cored at Hole $638 \mathrm{C}$ can be assigned to the same early Valanginian Subzone (CC3a) as that distinguished for the marls of Hole 639A. Ages based on foraminifers are equivalent but must be considered to be putative, because this group is poorly represented at Hole 638C. Three dinoflagellate markers (Biorbifera johnewingii, Dingodinium cerviculum, and Druggidium apicopaucicum) have simultaneous first occurrences in Core 103$638 \mathrm{C}-7 \mathrm{R}$. The first-appearance datum (FAD) of B. johnewingii is known to occur in the upper Berriasian (Habib and Drugg, 1983; Jardiné et al., 1984), and its acme is in the middle lower Valanginian (J.-F. Raynaud, pers. comm., 1985). According to Jardiné et al. (1984), D. cerviculum first appears at the Berriasian/Valanginian boundary but does not reach significant abundance prior to the upper Valanginian; however, Habib and Drugg (1987) recorded this species as earlier in the Berriasian. The third marker, D. apicopaucicum, first appears just above the lower boundary of the ammonite Pertransiens Zone (= early, but not basal, Valanginian) (Habib, 1977; Habib and Drugg, 1983; Jardiné et al., 1984). Thus, the lower part of Hole 638C, which is barren of dinoflagellate cysts, could be as old as Berriasian. However, in consideration of the poor conditions of fossilization (i.e., low assemblage diversity with few specimens) in the sandstones, it seems more likely that the first occurrences depicted in Hole 638C do not coincide with real FADs and that the entire section recovered at Hole $638 \mathrm{C}$ is of early Valanginian age. This suggests that the sandstones in Holes 638B and 638C are of approximately the same age (and probably slightly younger) as the marls of Hole 639A. 


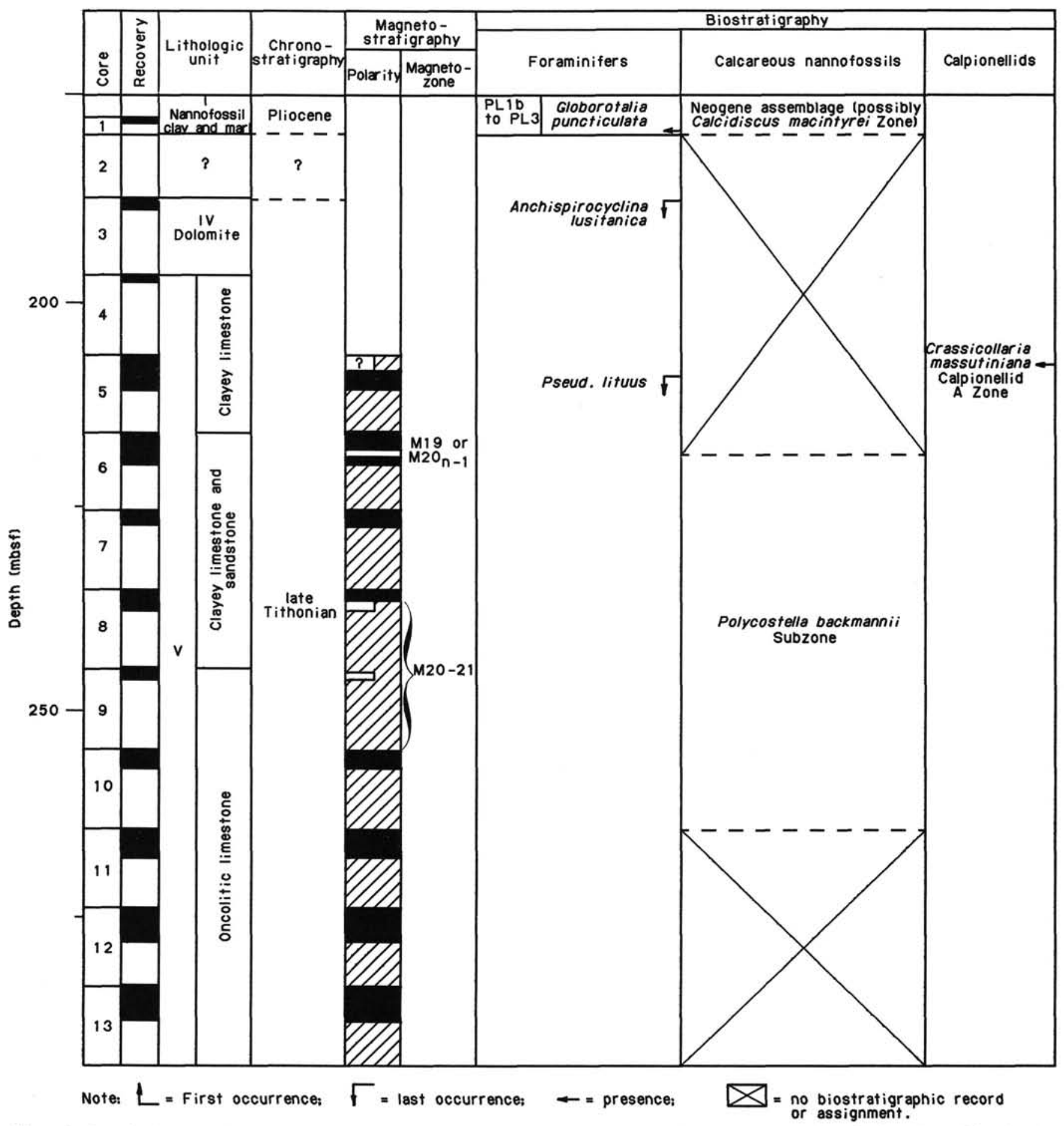

Figure 1. Jurassic chronostratigraphy, magnetostratigraphy, and biostratigraphy, ODP Hole 639D. Magnetostratigraphy from Ogg (this volume). Biostratigraphy from Boillot, Winterer, et al. (1987) with additional foraminifer data from Moullade et al. (this volume). In polarity column, black indicates normal polarity zones and white is reversed polarity; diagonal pattern indicates gaps in recovery or intervals of indeterminate or unreliable polarity; half bar represents a single sample having a polarity interpretation opposite that of the adjacent samples or indicates that only one sample was available from the core.

According to dinoflagellate data, sediments of early Valanginian age extend up to, but do not include, Section 103-638B37R-1. The first occurrence of Druggidium deflandrei in this sample indicates that it is within the upper Valanginian.

\section{Correlation between Holes $638 \mathrm{C}$ and $638 \mathrm{~B}$}

Based on their respective sub-bottom depths, the two deepest cores of Hole 638B correlate with the two shallowest cores of
Hole $638 \mathrm{C}$. This is consistent with the nannofossil zonal assignments: Cores 103-638B-44R and 103-638B-45R and the interval from Cores $103-638 \mathrm{C}-1 \mathrm{R}$ to $103-638 \mathrm{C}-10 \mathrm{R}$ are attributed to the $T$. verenae Subzone (CC3a).

\section{Possible Hiatuses in the Lower Cretaceous Sequence}

Based on nannofossil data, a hiatus or, at the least, a zone characterized by extreme sedimentary condensation is suspected 


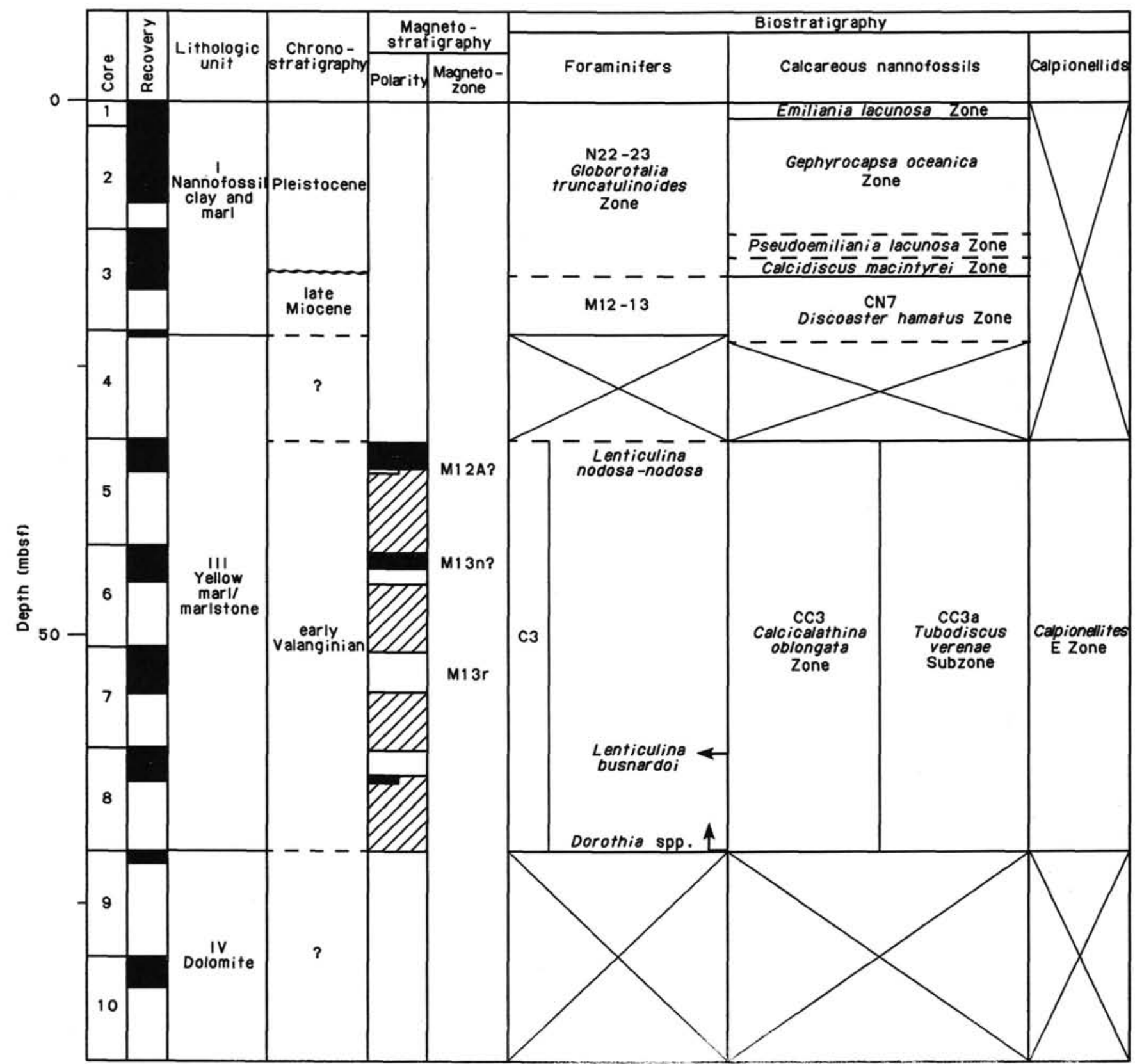

Figure 2. Cretaceous chronostratigraphy, magnetostratigraphy, and biostratigraphy, ODP Hole 639A. Magnetostratigraphy from Ogg (this volume). In polarity column, black indicates normal polarity zones and white is reversed polarity; diagonal pattern indicates gaps in recovery or intervals of indeterminate or unreliable polarity; half bar represents a single sample having a polarity interpretation opposite that of the adjacent samples or indicates that only one sample was available from the core. Biostratigraphy from Boillot, Winterer, et al. (1987), with additional calcareous nannofossil data from Wei et al. (this volume) and Applegate and Bergen (this volume). Symbols explained in Figure 1.

in Core 103-638B-23R, in which Zone CC5 (= early Barremian) is documented in only one sample. In addition, biostratigraphic dating of the Lower Cretaceous section drilled at Hole 638B shows a striking, well-defined uphole trend toward strong slowing of the sediment-accumulation rate as follows: $40 \mathrm{~m} / \mathrm{m}$.y. in the Valanginian, $10 \mathrm{~m} / \mathrm{m} . \mathrm{y}$. in the Hauterivian, and $5 \mathrm{~m} / \mathrm{m} . \mathrm{y}$. in the Barremian.

\section{Age of the Uppermost Cretaceous Section Overlain Unconformably by Neogene Sediments}

Foraminifers, nannofossils, and radiolarians all indicate that the age of the topmost Cretaceous section of Hole 638B, from
Core 103-638B-22R to the lower part of Core 103-638B-20R, is Barremian (this interval is directly overlain by a sequence of late Miocene-early Pleistocene age nannofossil ooze; see the following text). According to Drugg and Habib (this volume), the occurrence of the dinoflagellates Muderongia simplex and Phoberocysta neocomica together indicates that Section 103-638B21R-2 is not younger than Barremian. However, Masure (this volume) suggested that Sample 103-638B-21R-2, 121-123 cm, is late Aptian on the basis of the first occurrence of Oligosphaeridium verrucosum, and Taugourdeau-Lantz (this volume) assigned an Aptian-early Albian age to this core from pollen evidence. These discrepancies may be the result of calibration problems. 


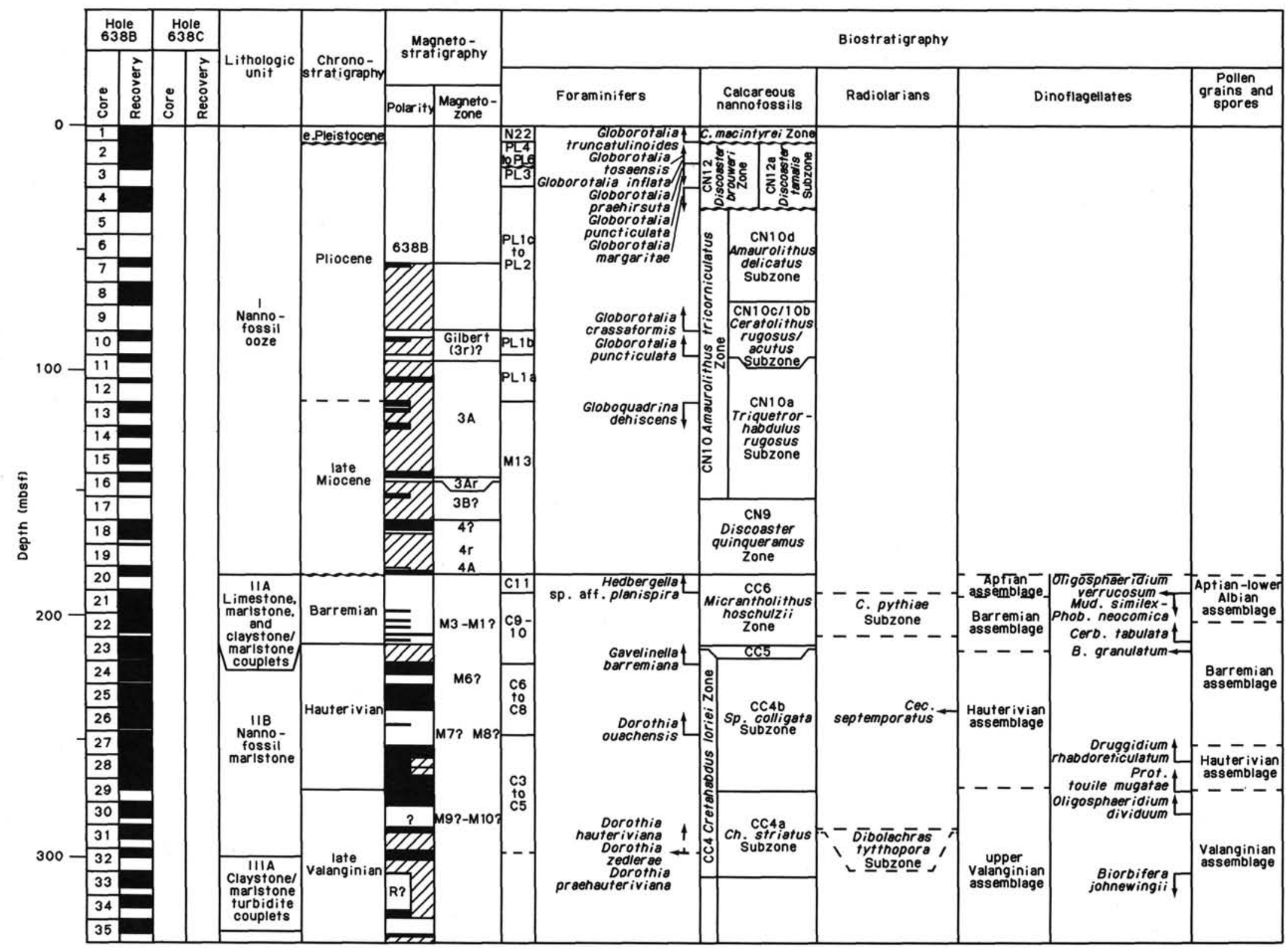

Figure 3. Cretaceous and Neogene chronostratigraphy, magnetostratigraphy, and biostratigraphy, ODP Holes 638B and 638C. Magnetostratigraphy modified after Ogg (this volume). In polarity column, black indicates normal polarity zones and white is reversed polarity; diagonal pattern indicates gaps in recovery or intervals of indeterminate or unreliable polarity; half bar represents a single sample having a polarity interpretation opposite that of the adjacent samples or indicates that only one sample was available from the core. Biostratigraphy modified after Boillot, Winterer, et al. (1987) and from A. Mouichni (pers. comm., 1987) for foraminifers; Wei et al. (this volume) and Applegate and Bergen (this volume) for calcareous nannofossils; Thurow (this volume) for radiolarians; Masure (this volume), Drugg and Habib (this volume), and this study for dinoflagellates; and Taugourdeau-Lantz (this volume) for pollen grains and spores. Symbols explained in Figure 1. 


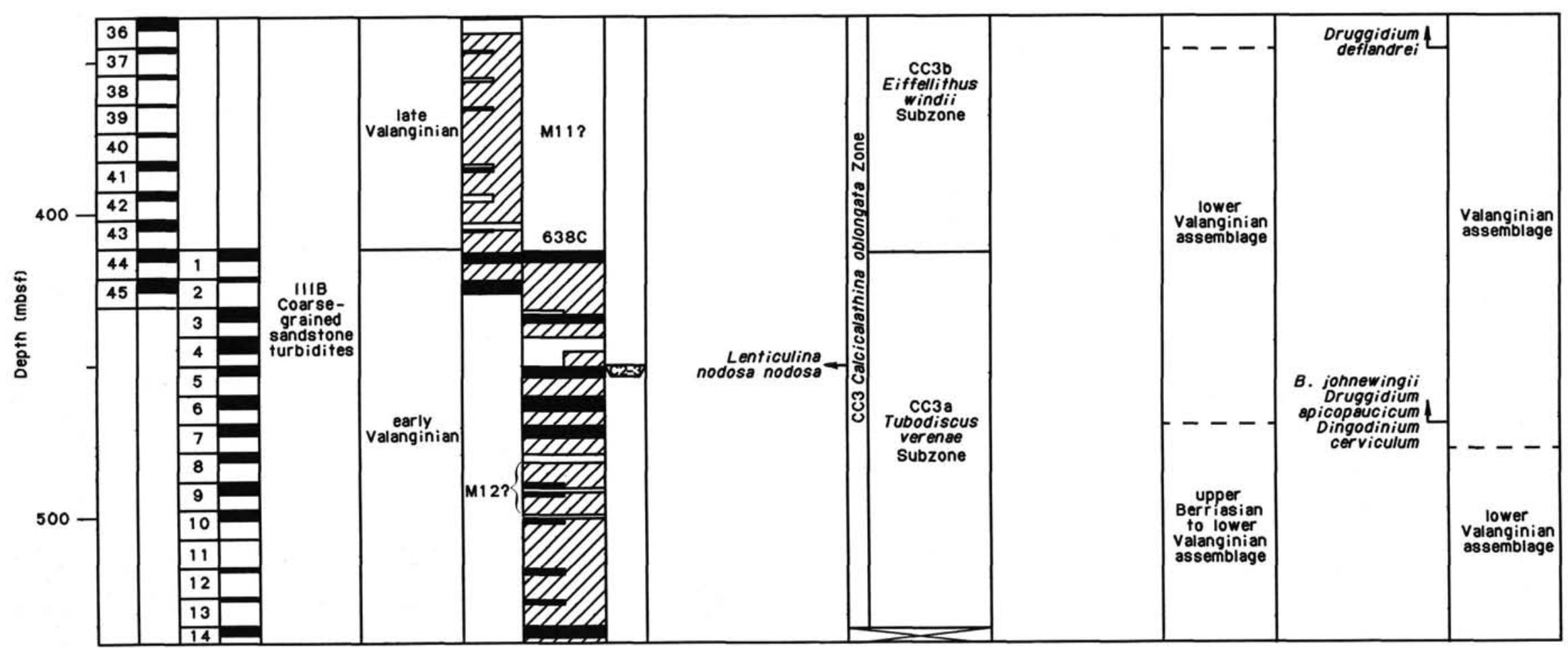

Figure 3 (continued). 


\section{Hole 641C (Fig. 4)}

Approximately $300 \mathrm{~m}$ of "middle" Cretaceous sediments was drilled at Hole 641C. Foraminifers, dinoflagellates, and nannofossils (Zone CC6) indicate that the deepest part of the section is late Barremian in age, which correlates chronostratigraphically with the top of the Lower Cretaceous section at Hole 638B.

The boundary between nannofossil Zones CC6 and CC7 places the Barremian/Aptian boundary in the lower part of Core 103-641C-11R. Foraminifers indicate a slightly deeper position, based on the first appearance of Globigerinelloides, between Cores 103-641C-12R and 103-641C-13R. The Barremian/ Aptian boundary is placed within Core 103-641C-12R by dinoflagellates. These microfossil groups indicate that the placement of magnetic Chron M0 at Core 103-641C-10R is dated as early Aptian. A precise dating of the upper Aptian-lower Albian beds can be obtained from foraminifer zones. In particular, the discontinuity (break-up unconformity) appearing between lithologic Units III and IV (see Boillot, Winterer, et al., 1987) is dated as latest Aptian. The upper part of the black clay interval cored at Hole 641C (Cores 103-641C-1R to 103-641C-3R) is given a late Albian age by dinoflagellates (Drugg and Habib, this volume) and pollen grains (Thurow et al., this volume).

\section{Hole 640A (Fig. 5)}

Dating by microfossils shows that most (Core 103-640A-9R to Sample 103-640A-2R-2, $60 \mathrm{~cm}$ ) of the Mesozoic part of the section drilled at Hole $640 \mathrm{~A}$ consists of upper Hauterivian-Bar-

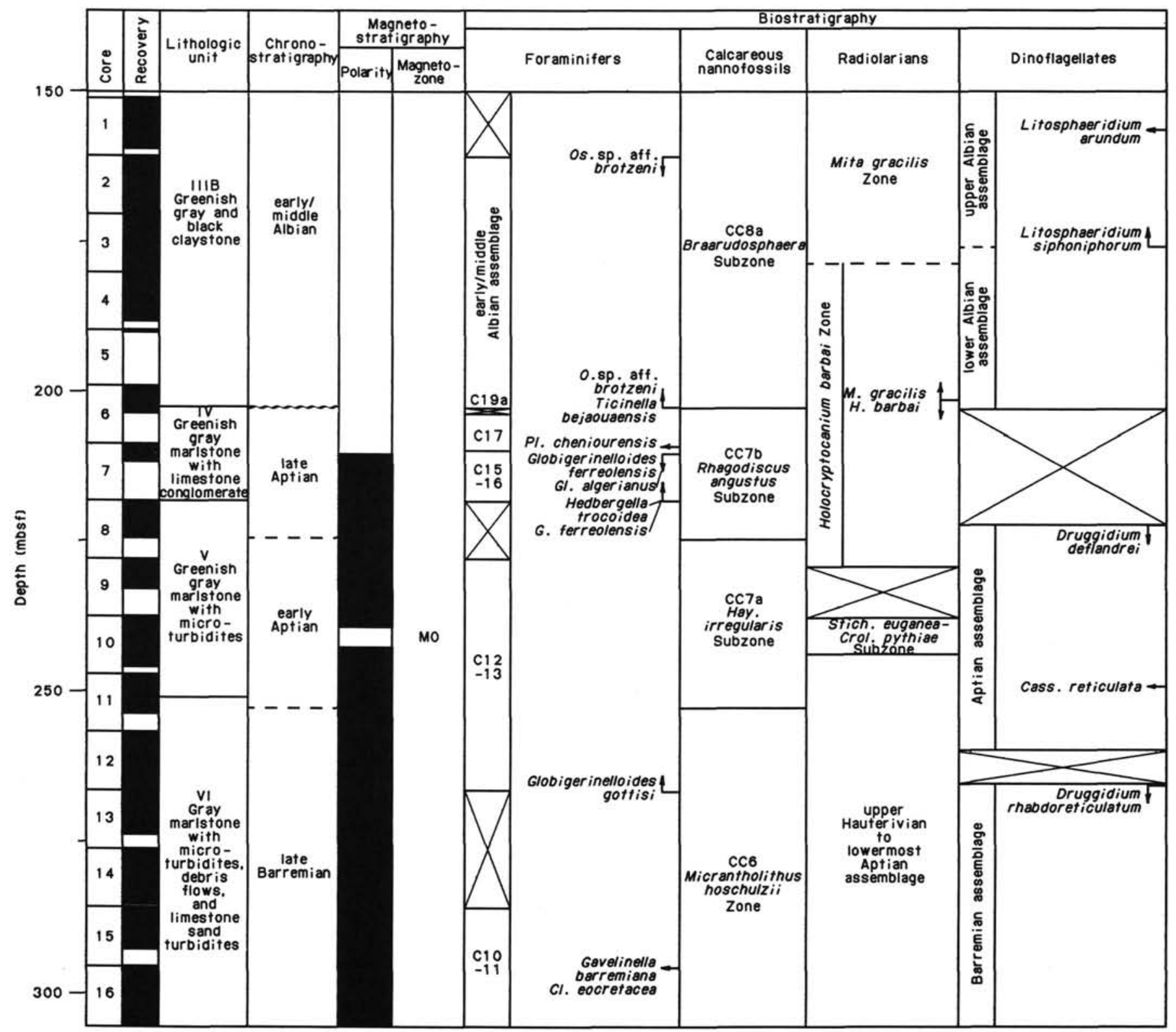

Figure 4. Cretaceous chronostratigraphy, magnetostratigraphy, and biostratigraphy, ODP Hole 641C. Magnetostratigraphy modified after Ogg (this volume). In polarity column, black indicates normal polarity zones and white is reversed polarity; diagonal pattern indicates gaps in recovery or intervals of indeterminate or unreliable polarity; half bar represents a single sample having a polarity interpretation opposite that of the adjacent samples or indicates that only one sample was available from the core. Biostratigraphy modified after Boillot, Winterer, et al. (1987) for foraminifers; Applegate and Bergen (this volume) for calcareous nannofossils; Thurow (this volume) for radiolarians; and Drugg and Habib (this volume) for dinoflagellates. Symbols explained in Figure 1. 
BIOSTRATIGRAPHIC SYNTHESIS

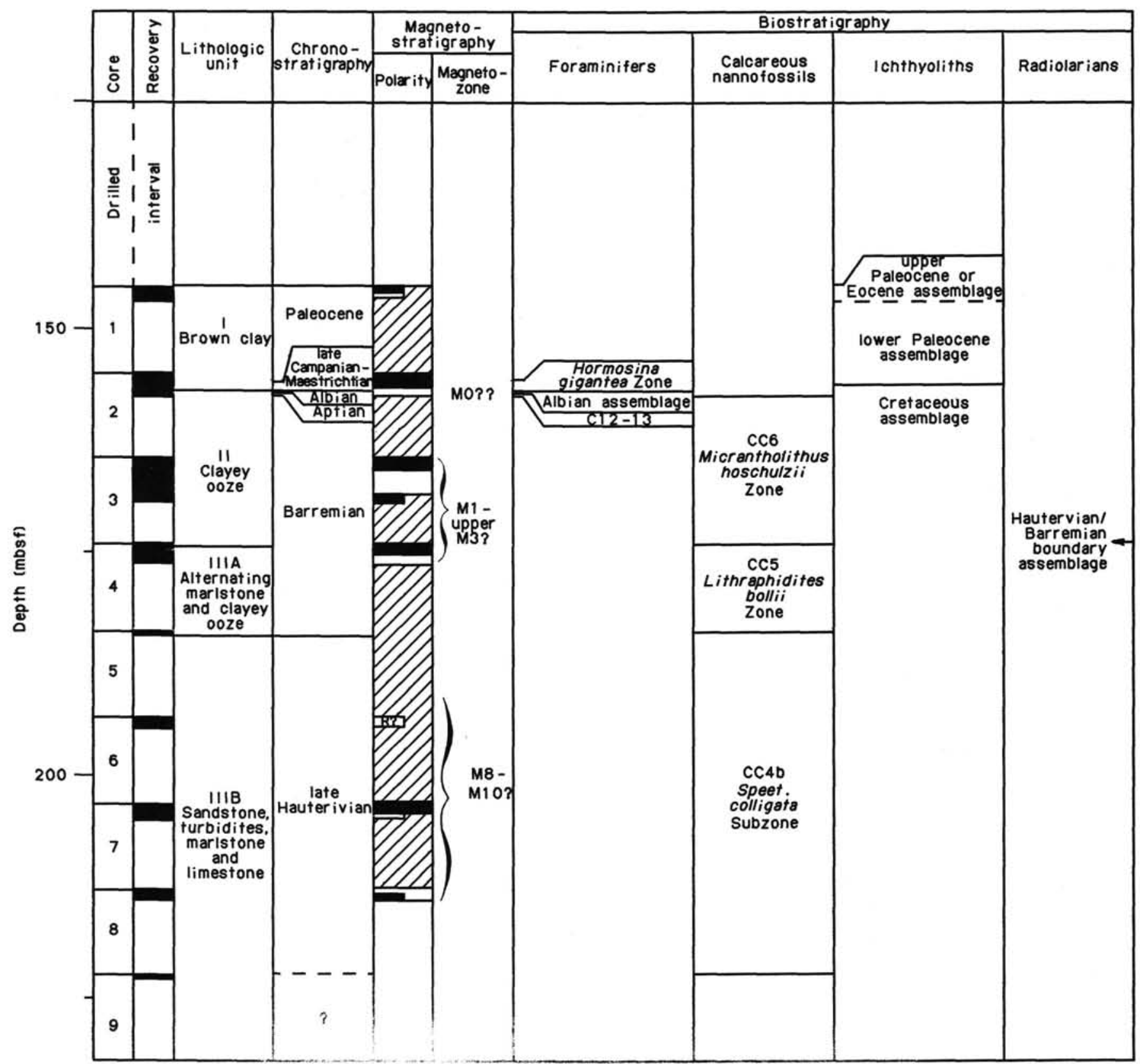

Figure 5. Cretaceous and Paleogene chronostratigraphy, magnetostratigraphy, and biostratigraphy, ODP Hole 640A. Magnetostratigraphy modified after Ogg (this volume). In polarity column, black indicates normal polarity zones and white is reversed polarity; diagonal pattern indicates gaps in recovery or intervals of indeterminate or unreliable polarity; half bar represents a single sample having a polarity interpretation opposite that of the adjacent samples or indicates that only one sample was available from the core. Biostratigraphy modified after Boillot, Winterer, et al. (1987) and Moullade et al. (this volume) for foraminifers; Applegate and Bergen (this volume) for calcareous nannofossils; Doyle (this volume) for ichthyoliths; and Thurow (this volume) for radiolarians. Symbols explained in Figure 1.

remian sediments. These Neocomian rocks recovered at Site 640 are about $75 \mathrm{~m}$ thick and are overlain by an extremely condensed, 60-cm-thick interval (above $60 \mathrm{~cm}$ in Section 103-640A2R-2) for which Aptian, Albian, and late Campanian-Maestrichtian ages are determined from recovered foraminifers. Thus, this hole not only has a strongly condensed sedimentary interval in the middle to Upper Cretaceous, but also contains significant hiatuses (e.g., Cenomanian to lower Campanian).

\section{Hole 641A (Fig. 6)}

The deepest part of Hole 641A (Core 103-641A-7R and Sample 103-641A-6X, CC [20-45 cm]) consists of green-gray marls of latest Albian (foraminifer Zone C26, late Vraconian) and early Cenomanian (C27) age. This foraminiferal dating is confirmed by nannofossil data (CC9b and CC10a Subzones). However, the greenish gray clayey interval from 20 to $45 \mathrm{~cm}$ in the core catcher of Core 103-641A-6X (regarded as early Cenomanian from foraminifers and early to middle Cenomanian using nannofossils) is dated as middle to late Cenomanian by Masure (in Thurow et al., this volume) using dinoflagellates, earliest Turonian by Drugg and Habib (this volume) using dinoflagellates and pollen grains, and late Cenomanian by Taugourdeau-Lantz (in Thurow et al., this volume) using pollen grains.

The 25 -cm-thick black clay interval that overlies the greenish gray marls is barren of foraminifers and nannofossils. Accord- 


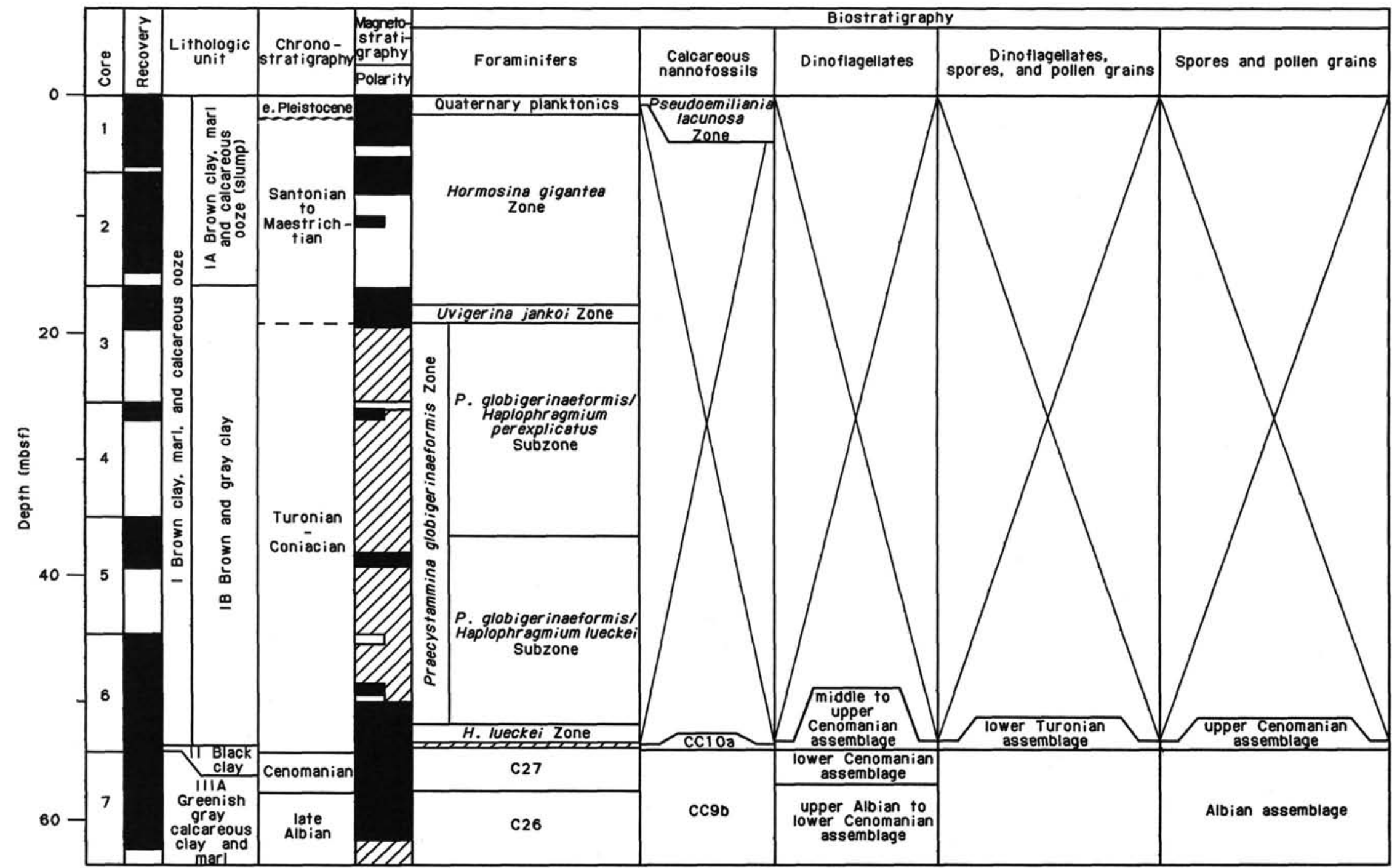

Figure 6. Cretaceous chronostratigraphy, magnetostratigraphy, and biostratigraphy, ODP Hole 641C. Magnetostratigraphy modified after Boillot, Winterer, et al. (1987). In polarity column, black indicates normal polarity zones and white is reversed polarity; diagonal pattern indicates gaps in recovery or intervals of indeterminate or unreliable polarity; half bar represents a single sample having a polarity interpretation opposite that of the adjacent samples or indicates that only one sample was available from the core. Biostratigraphy modified after Moullade et al. (this volume) for foraminifers; Wei et al. (this volume) and Applegate and Bergen (this volume) for calcareous nannofossils; Masure (this volume) and Thurow (this volume) for radiolarians; Thurow et al. (this volume) for spores and pollen grains; and Drugg and Habib (this volume) for dinoflagellates, spores, and pollen grains. Symbols explained in Figure 1. 
ing to Masure (Thurow et al., this volume), the top of the black clay band contains dinoflagellates that still suggest a middle to late Cenomanian age. The top of the black clay layer is earliest Turonian according to Drugg and Habib (this volume) and late Cenomanian according to Taugourdeau-Lantz (in Thurow et al., this volume).

The 50-m-thick brown clay that overlies the black clay contains only agglutinated benthic foraminifers, which indicate that this section is of (late) Turonian age at its base and represents a complete Late Cretaceous sequence. This dating is consistent with the early Turonian age indicated by Drugg and Habib (this volume), but consideration of the preceding suggested Cenomanian age indicates a hiatus or at least a process of condensation during the early Turonian. Based on foraminifers, a (late) Turonian-Coniacian age is suggested from Core 103-641A-6X (above the black band) to the lower part of Core 103-641A-3X, and a Santonian to Maestrichtian age from the upper part of Core 103-641A-3X to the upper part of Core 103-641A-1X, the top part of which is Pleistocene. This foraminiferal dating allows us to attribute the magnetic polarity pattern obtained for the upper part of the brown clay sequence tentatively to Chrons 33-31.

\section{CENOZOIC}

\section{Paleogene}

\section{Hole 640A (Fig. 5)}

Ichthyoliths found in the brown clay of Core 103-640A-1R indicate a late Paleocene, or possibly early Eocene, age. According to Doyle (this volume), ichthyolith assemblages also suggest that the Cretaceous/Tertiary boundary occurs between 84 and $103 \mathrm{~cm}$ in Section 103-640A-2R-1. According to Moullade et al. (this volume), an agglutinated benthic foraminiferal assemblage of the Hormosina gigantea Zone is present in Sample $103-640 \mathrm{~A}-2 \mathrm{R}-2,30-32 \mathrm{~cm}$. The indicated age of not younger than middle Maestrichtian is consistent with the ichthyolithbased age assignment.

\section{Hole 637A (Fig. 7)}

Paleocene and Eocene ichthyolith assemblages were found also in the reddish brown clay (Cores 103-637A-23R to 103637A-21 R) that overlies the peridotite at Hole 637A. As in Hole $640 \mathrm{~A}$, these brown clayey levels are devoid of calcareous microfossils.

\section{Neogene-Quaternary}

During ODP Leg 103, significant Neogene-Quaternary sections were recovered only at Holes $637 \mathrm{~A}$ and $638 \mathrm{~B}$. Their biostratigraphic analysis is complicated by (1) insufficient core recovery; (2) unusually high downhole contamination; (3) sedimentary and microfaunal reworking and disturbance (turbidites, slumps, and hiatuses); (4) low representation of the warmwater planktonic foraminifers and nannofossil discoasters, which constitute the best markers among the microfaunal calcareous assemblages; and (5) the total dissolution of calcareous microfossils below Core 103-637A-20R.

However, nannofossils and, to a slightly lesser degree, planktonic foraminifers allow determination of the upper Miocene, Pliocene, and (mostly lower) Pleistocene, as well as several hiatuses, in both sequences.

\section{Hole 637A (Fig. 7)}

Based on the discontinuous and extremely low sediment-accumulation rates or missing biozones, four (erosional?) hiatuses are either suspected or precisely documented in the $190 \mathrm{~m}$ of Neogene-Quaternary sediments recovered in Hole 637A.
Extremely low sediment-accumulation rates (compared to the average rate for the biozones immediately above and below) characterize the nannofossil Subzones CN10b-10c (Core 103637A-18R) (Wei et al., this volume), suggested the possible existence of a hiatus in the early Pliocene. In the same core, the abnormal simultaneous first occurrences of the planktonic foraminifers Globorotalia margaritae and Globorotalia puncticulata confirm the hiatus suspected from the nannofossil data and imply that at least the foraminifer PL1a Subzone (earliest Pliocene) is missing.

A second hiatus is suspected in the middle part of the Pliocene (the lower part of Core 103-637A-15R and the top part of Core 103-637A-16R), based on the sudden drop of the sediment-accumulation rate calculated for the nannofossil $\mathrm{CN12a}$ Subzone (Wei et al., this volume). This hiatus cannot be confirmed by the foraminifer distribution pattern.

In Core 103-637A-13R, Subzone CN12d directly overlies Subzone $\mathrm{CN} 12 \mathrm{~b}$ because Subzone $\mathrm{CN} 12 \mathrm{c}$ is missing. At this same depth, the last-appearance datum (LAD) of Neogloboquadrina atlantica (which disappears at the foraminiferal zonal boundary PL5/6; K. Ma'alouleh, pers. comm., 1987) is abnormally coincident with the FAD of Globorotalia truncatulinoides, thus indicating that Zone PL6 (=latest Pliocene) is missing.

The top of the Neogene-Quaternary sequence drilled at Hole 637 A appears to be truncated. Most of the upper Pleistocene and Holocene are missing and/or only partially cored, in consideration that recovery in Core 103-637A-1R is limited to the core-catcher sample.

\section{Hole 638B (Fig. 3)}

The 180-m-thick Neogene-Quaternary sequence drilled at Hole $638 \mathrm{~B}$ is also marked by truncation and hiatuses, though the calculated average sediment-accumulation rate in comparison to that of Hole $637 \mathrm{~A}$ appears twice as high and is even higher for particular intervals (e.g., the upper Miocene and lower Pliocene section is $40 \mathrm{~m}$ thick at Hole 637A and $175 \mathrm{~m}$ thick at Hole 638B).

In the bottommost part of Core 103-638B-4R, nannofossil Zone $\mathrm{CN} 12$ directly overlies Zone CN10; the minimum estimated duration of the hiatus, which corresponds to at least Zone CN11, is 0.3 m.y.

The last occurrence of $G$. puncticulata and the first occurrence of Globorotalia inflata in Section 103-638B-2R, CC, would indicate the PL3/4 zonal boundary, except for the simultaneous occurrence of two other events that are considered slightly younger (= middle of PL4), the LAD of Globorotalia praehirsuta and the FAD of Globorotalia tosaensis. The indicated additional possible hiatus would correspond to part of Zones PL3 and PL4.

In Section 103-638B-2R-1, the nannofossil Subzones CN12b$12 \mathrm{~d}$ are missing.

The attribution of the only first core of Hole 638B to the nannofossil Calcidiscus macintyrei Zone (sensu Gartner) and the foraminifer Zone N22 assigns it an early Pleistocene age. This assignation indicates that most of the Quaternary is missing in Hole 638B.

In addition to these hiatuses, an interval in Cores 103-638B$3 \mathrm{R}$ and $103-638 \mathrm{~B}-2 \mathrm{R}$ (of late Pliocene age) is marked by significant reworking of older forms, with early Pliocene, Miocene, and even a few Late Cretaceous foraminifers occurring as a consistent $5 \%$ to $20 \%$ admixture with the in-situ microfauna.

\section{ACKNOWLEDGMENTS}

M. Moullade, J. L. Applegate, J. A. Bergen, J. Ogg, and J. Thurow wish to thank ODP for inviting them to participate in Leg 103. The authors are also indebted to Mrs. Mouichni (University of Rabat, Mo- 


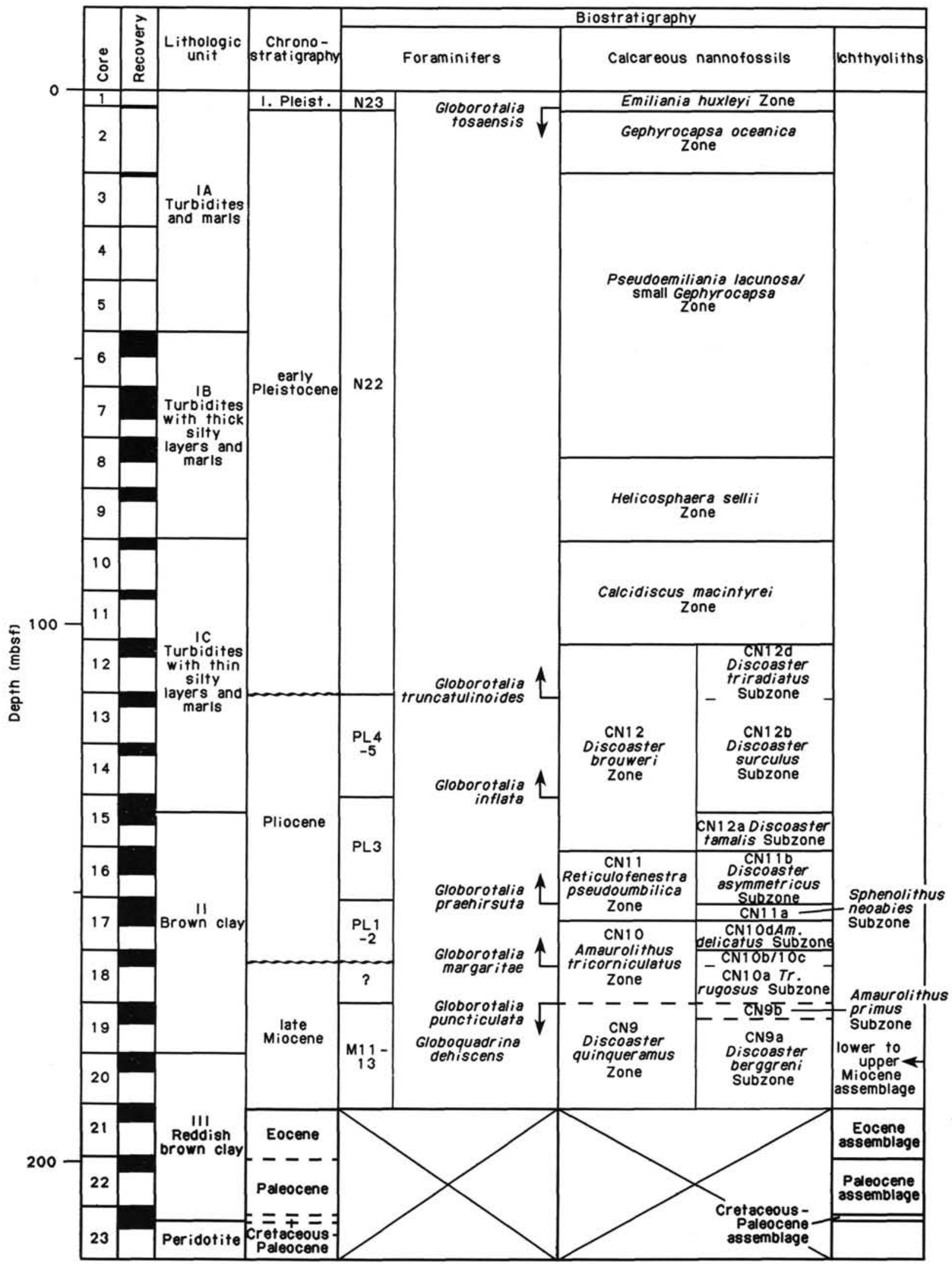

Figure 7. Cretaceous and Cenozoic chronostratigraphy and biostratigraphy, ODP Hole 637A. Magnetostratigraphy modified after Ogg (this volume). In polarity column, black indicates normal polarity zones and white is reversed polarity; diagonal pattern indicates gaps in recovery or intervals of indeterminate or unreliable polarity; half bar represents a single sample having a polarity interpretation opposite that of the adjacent samples or indicates that only one sample was available from the core. Biostratigraphy modified after Boillot, Winterer, et al. (1987) and from A. Mouichni (pers. comm., 1987) for foraminifers; Wei et al. (this volume) for calcareous nannofossils; and Doyle (this volume) for ichthyoliths. Symbols explained in Figure 1. 
rocco) for communicating the results of a restudy of Neogene-Quaternary foraminifers from Holes 637A and 638B.

\section{REFERENCES}

Boillot, G., Winterer, E. L., et al., 1987. Proc. ODP, Init. Repts., 103: College Station, TX (Ocean Drilling Program).

Habib, D., 1977. Comparison of Lower and middle Cretaceous palynostratigraphic zonations in the western North Atlantic. In Swain F. W. (Ed.), Stratigraphic Micropaleontology of Atlantic Basin and Borderlands: Amsterdam (Elsevier), 887-897.

Habib, D., and Drugg, W. S., 1983. Dinoflagellate age of Middle Jurassic-Early Cretaceous sediments in the Blake-Bahama Basin. In Sheri- dan, R. E., Gradstein, F. M., et al., Init. Repts. DSDP, 76: Washington (U.S. Govt. Printing Office), 623-635.

1987. Palynology of Sites 603 and 605, Deep Sea Drilling Project. In van Hinte, J. E., Wise, S. W., Jr., et al., Init. Repts. DSDP, 93: Washington (U.S. Govt. Printing Office), 751-775.

Jardiné, S., Raynaud, J.-F., and de Reneville, F., 1984. Dinoflagellés, spores et pollens. Crétacé inférieur. In Debrand-Passard, S., Courbouleix, S., and Lienhardt, M.-J. (Eds.), Synthèse Géologique du Sud-Est de la France: Mem. B.R.G.M., 125:300-303.

Date of initial receipt: 17 November 1987

Date of acceptance: 15 February 1988

Ms 103B-176 